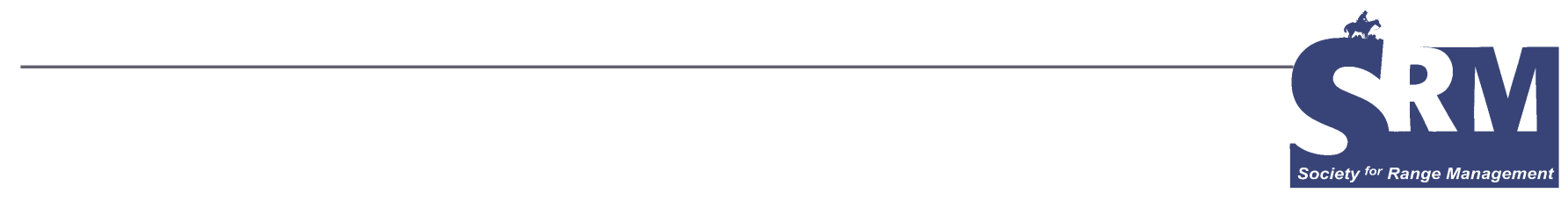

\title{
Seventy Years of Pasture Rejuvenation Research
}

\section{By Duane McCartney}

Editor's Note: This article is a reprint from a handout brochure of the Western Forage and Beef Group, Volume 10, Issue 3, 2006.

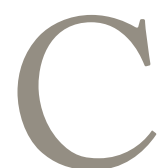

attle grazing on community pastures is part of the history of Western Canada. The idea of developing community pastures was conceived in 1922 with the establishment of the Matador pasture, $48 \mathrm{~km}$ north of the city of Swift Current, Saskatchewan. Later in the 1960s and 1970s, an international research center was established at the Matador pasture as part of a world-wide attempt to collect data on representative ecosystems and to develop computer models of them. Many of the world's present-day ecologists worked in the program as student help during data collection and analysis. The results were published in approximately 25 volumes, each the size of a big city phone book. A summary of the overall results can be found on www.foragebeef.ca.

During the "Dirty Thirties" researchers at Agriculture and Agri-Food Canada at Swift Current and Prairie Farm Rehabilitation Administration (PFRA) began to reestablish drought-stricken pastures in the southern prairies with new varieties of Russian wild rye and crested wheat grass. The involvement of PFRA in pasture and range development started in 1935 along with soil reclamation, tree planting, and water development projects. By the end of 1937,16 provincial community pastures involving 175,900 acres had been established in Saskatchewan. In addition, thirty more potential pasture areas had been surveyed for development encompassing about 400,000 acres, and 5 reserve areas were proposed to be taken out of annual cropping, reseeded to grass, and used for supplemental forage for wintering livestock. Eight pastures totaling
595,840 acres were established by the Alberta government during this time.

Many additional community pastures were developed in Saskatchewan in the 1950s and 1960s. The land came from vacant crown land, grazing leases, and from the purchase of private land. The land was marginal for cultivation and farmers on nonviable farm units were assisted to relocate or they left farming. During this time pasture development moved into the aspen parkland and forest fringe areas. Many of these areas required the clearing of tree growth and the seeding to tame forage species. The last community pasture in Saskatchewan was established in 1971, and currently the main objective for community pastures is to sustain forage production at an optimum level.

In order to clear, break, cultivate, and reseed these bushland pastures, very unique equipment was developed. Researchers at Agriculture and Agri-Food Canada Beaverlodge, Melfort, Swift Current, as well as the Provincial Lands Branch agrologists were involved. Pastures were often seeded to a "shotgun" mixture of 17 different grasses and legumes, including creeping red fescue, blue grass, and smooth brome grass with the hope that something could be established over the entire ecosystem of the newly developed pasture.

A large multidisciplinary research project was established by the Melfort Research Station in 1975 to develop methods to rejuvenate overgrazed and depleted roughland bush pastures in the aspen parkland. The Pathlow Project, as it was known, was a joint effort of Agriculture and AgriFood Canada, Saskatchewan Agriculture Lands Branch, and the Saskatchewan Horned Cattle Trust Fund. The purpose was to look at different grazing management 

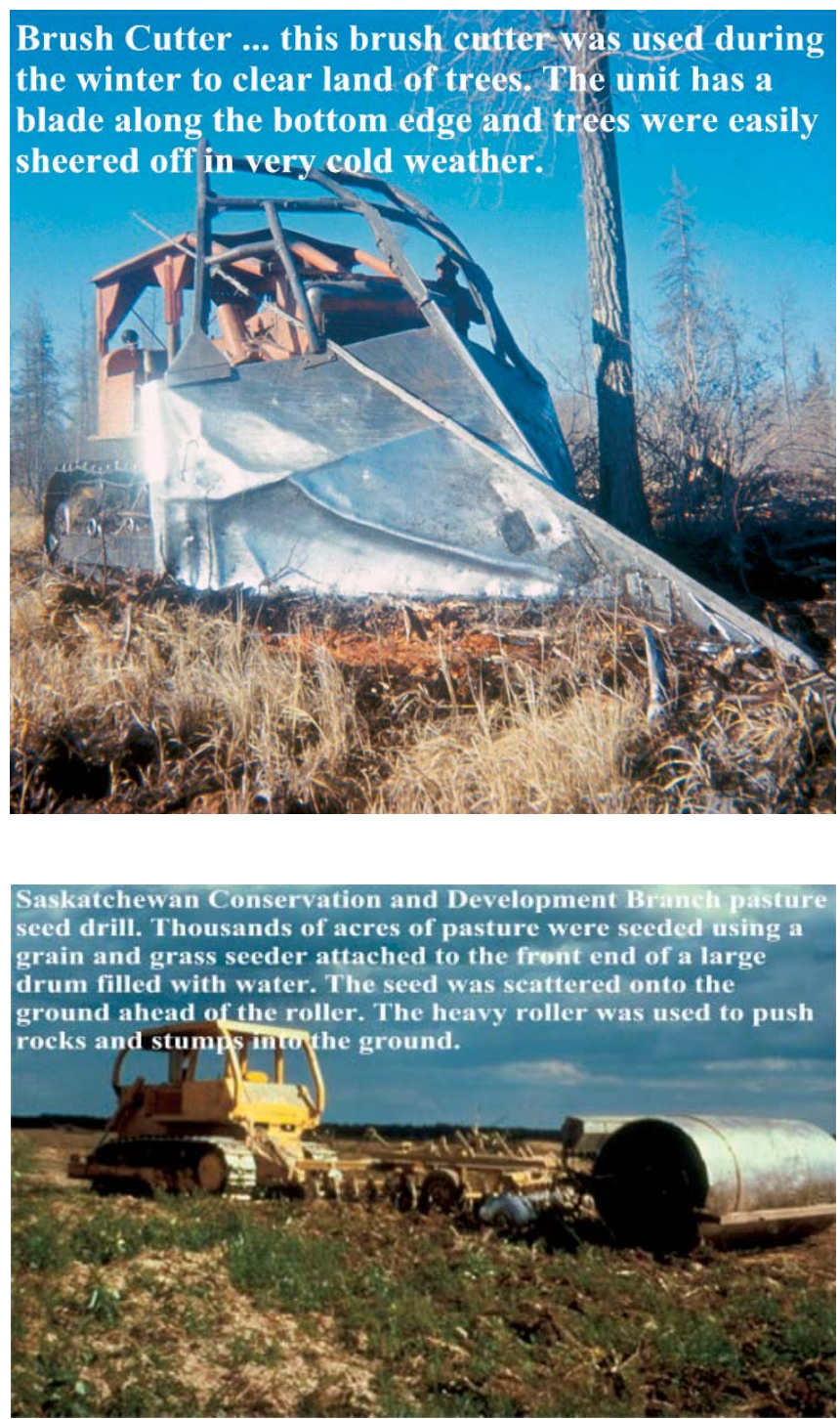

systems, soil fertility, forage species adaptation, diversity, and extension of the grazing season.

Initially, Russian wild rye grass and crested wheat grass were seeded for early grazing. The Russian wild rye grass was difficult to establish and basically only grew on the drier hills. It could not compete with volunteer blue grass and smooth brome grass on the drier areas. Crested wheat grass established very well. It was heavily grazed for 2 to 3 weeks early in the grazing season so that it did not go to seed. These grazing areas were allowed to rest for the remainder of the growing season and were later grazed in the fall. This provided about 2 weeks of extra grazing in the spring and another 2 weeks in the fall, compared to the remainder of the perennial pastures.

A unique grazing trial was later established to assess how individual grass and legume species could survive under different levels of grazing pressure. The "Mob grazing trial" consisted of a large number of cattle grazing the plot area: 1) 5 times a year to simulate continuous grazing; 2) a light grazing twice a year in mid-June and mid-September; and 3) a third moderate treatment of the grazing 3 times a year. The cattle were left on the treatment areas for 1 to 2 days until all vegetation had been grazed down. Thirteen cool-season grass species and 9 alfalfa species were evaluated for several years for persistence. Parkway crested wheat grass, Carlton smooth brome grass, and meadow brome grass were the most persistent. Intermediate wheat grass and northern wheat grass disappeared the quickest and were replaced by bluegrass. The falcate type of alfalfa with yellow flowers had the greatest persistence of all the alfalfas tested. As a result of this initial trial a new variety of alfalfa called "Yellowhead" will officially be released for use in the coming year. However, this will depend on seed supply.

Yellowhead alfalfa 20 years after seeding. This plot of Yellowhead alfalfa was seeded in 1986 at the Pathlow Pasture Research site in Saskatchewan. It has been subjected to different periods of grazing and rest over the years.

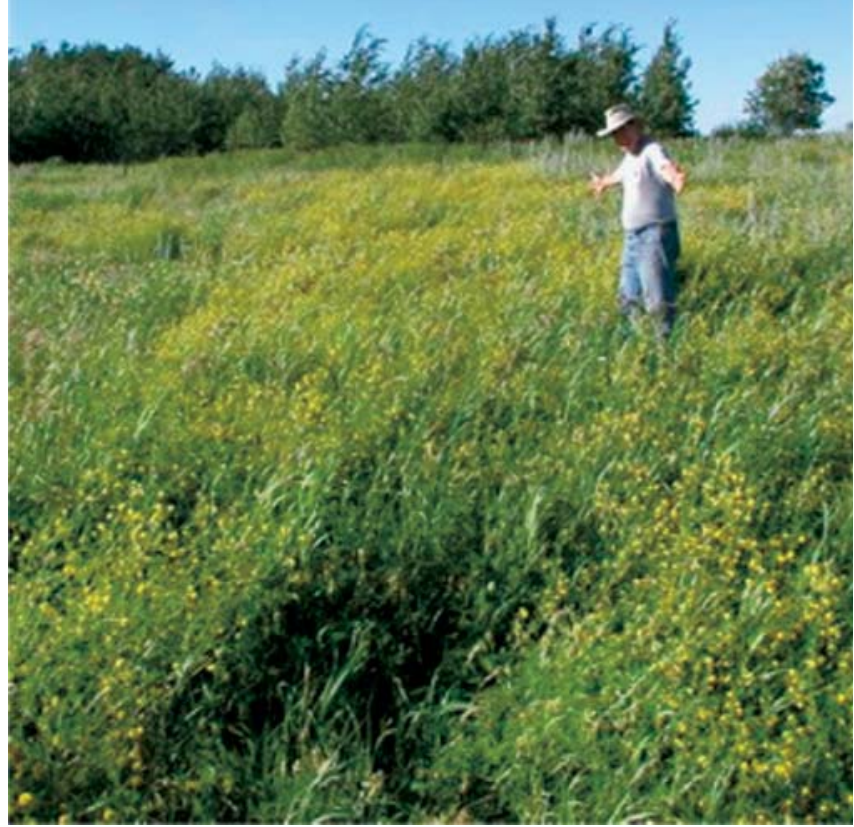

Over the years, additional fertility, species selection, seeding methods, and pasture monitoring systems were developed through the Pathlow Research Project. Summaries of these projects can be found on www.foragebeef.ca.

Several areas of the research site were seeded to tame forages. However, over time these sites were taken over by invading blue grass and smooth brome grass. Because these pastures had been seeded to the original "shotgun mixture," including blue grass and smooth brome grass in the mid 1960s, the soil contained a large seed bank of dormant blue grass and smooth brome grass seed. If the objective of pasture reseeding on your farm is to establish a different 
species on the landscape, then it would be advisable to seed an annual cereal on this land for a few years in order to reduce the impact of the dormant seed bank. Kentucky blue grass (Poa pratensis) is a major component of pastures in the aspen parkland. It was likely the first cultivated grass to arrive in the new world from Europe and might have arrived in Canada in the early 1800s as referred to in "The dark side of Kentucky blue grass," Cattlemen Magazine (Oct. 2005).

Thirty years after the start of the Pathlow Pasture Project one can still learn from the ever-changing ecological system. Some of the overgrazed and depleted areas were allowed to rest for different periods of time.

I revisited the site this summer and found heavy stands of smooth brome grass where only minimal stands of blue grass and antennaria or everlasting (weed) previously grew. The vegetation on these fields was so sparse in the 1970s and 1980s that it only provided $2.2 \mathrm{AUM} \cdot \mathrm{ha}^{-1}$ of grazing. The crested wheat grass stands, when previously fertilized with $80 \mathrm{~kg}$ of $\mathrm{N}$ and $45 \mathrm{~kg}$ of $\mathrm{P}_{2} \mathrm{O}_{5}$, provided early and late fall grazing for about 10 years. These stands have now reverted back to the original smooth brome grass and blue grass swards. Over the years, the meadow brome grass has been dominated by smooth brome grass. Interestingly enough, in the former mob grazed area, the Yellowhead and Anik alfalfa have persisted for 20 years. During the past few years this area was not grazed.

Pasture stands have successfully been revitalized by allowing the forage species to rest until September for several years, followed by a heavy graze in the late fall. In these areas, a highly productive pasture stand was rejuvenated over the years at a very low cost.

From this long term pasture rejuvenation project, we have shown that depleted pastures in the aspen parkland can be rejuvenated through rest periods with no additional inputs.

For a complete summary of pasture rejuvenation research in Western Canada go to www.foragebeef.ca.

Author is Forage Beef Systems Research Scientist, Western Forage Beef Group, Agriculture and Agri-Food Canada, Lacombe, Alberta, Canada, email: mccartneyd@agr.gc.ca. 